\title{
EXTERNALITY AND MATERIALITY AS THEMES IN THE HISTORY OF THE HUMAN SCIENCES ${ }^{1}$
}

\author{
Henrik Sinding-Larsen ${ }^{\star}$
}

\begin{abstract}
This article presents and discusses some attempts to overcome the "Cartesian" dualism of "mind versus matter" and "interior versus exterior", in particular the attempts of anthropologist Tim Ingold in his book "The Perception of the Environment" (2000). Central to Ingold's argument is a shift in focus from structure to process (temporality), from design to growth, from the organism in a context to organism and environment as co-evolutionary and co-constitutive entities. Ingold builds on ecological thinking (Bateson and Gibson) and phenomenology (Merleau-Ponty and Heidegger). This article characterises Ingold's position as a neo-romantic reaction to the "linguistic turn" in the human sciences and the "genetic turn" in biology and compares his position to historical romanticism.
\end{abstract}

Keywords: Materiality. Cartesian dualism. Ecological perspective.

I will start with some words as a general background for what I mean by the concepts externality and materiality.

Central to the Western scientific project has been the recognition of two great dualities, namely:

- between mind and matter (linked to the immateriality of mind/soul versus the materiality of the body);

- between the inside or interior of the organism (comprising what we call the self) and the outside or exterior (usually identified as the environment).

The first division mind/matter actualises central questions of ontology: Does mind "exist" as a different kind of ontological entity than matter, and if so, can different entities of this kind interact? Or is the mind to be understood as only some part of the complex material processes of the brain and body?

If mind and matter are ontologically different, do they "obey" fundamentally different "laws"? For example, what kind of movement or agency is associated with mind versus matter? Is intentionality (and more specifically "free"

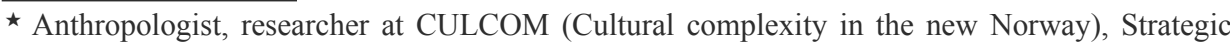
research programme, University of Oslo, Norway. Postal address: CULCOM c/o SAI, P.O. Box 1091 Blindern, N-0317 Oslo, Norway.

E-mail: henrik.sinding-larsen@culcom.uio.no
} 
intentionality or free will) to be found only in the mind? in both mind and matter, or only in matter? Or solely in the integrated entity of a living organism, or maybe only in the sub-category of self-conscious organisms?

If mind and matter are ontologically the same, would the idea of intentionality or free will have to be regarded as an illusion or just the result of our limited knowledge of the causal relationships in our brain and body?

The second division interior/exterior is related to questions of epistemology: Does the "exterior" in any direct way enter into the "interior" through perception (which would correspond to a realist position) or is the interior self-contained and projects its own structures onto the exterior (which would correspond to a constructivist position)? What kind of co-existence is possible between these two positions?

Much of the history of philosophy, as well as that of the human sciences, can be seen as different versions and combinations of how to understand the dualities linked to materiality and externality.

In 2000 the anthropologist Tim Ingold published the book The perception of the environment: essays in livelihood, dwelling and skill, in which he is concerned with the above-mentioned dualities and proposes some new(?) solutions as to how we should deal with them. I see Ingold's views as part of a larger trend within several disciplines of the human sciences, which have, during the last decade or two, been searching for new ways of dealing with these dualities, in particular news way of appreciating materiality. I consider myself to be part of this trend, and I have devoted considerable thought to the concept of externalisation as a key variable in cultural evolution (SINDING-LARSEN, 1991). My original motivation for the present paper was to try to see how my efforts were related to similar work within both contemporary and historical human science. My interest was caught by Ingold's book, which I will now discuss at some length, starting with a quote from the book's first page:

Concerned about the widening gap between the arts and the humanities on the one hand, and the natural sciences on the other, I was looking for a discipline that would somehow close the gap, or enable us to rise above it, while still remaining close to the realities of lived experience. Anthropology, for me, has been that discipline, and since embarking on it I have never looked back. I have, however, often looked from side to side, observing with mounting despair how it has been fractured along the very lines of fission that I thought it existed to overcome.

These fractures ultimately seem to derive from a single, underlying fault upon which the entire edifice of Western thought and science has been built - namely that which separates the "two worlds" of humanity and nature. For this is what has given us the overriding academic division of 
labour between the disciplines that deal, on the one hand, with the human mind and its manifold linguistic, social and cultural products, and on the other, with the structures and composition of the material world (INGOLD, 2000, p. 1, in this as well as in the quotations to follow, emphases in boldface are mine).

Ingold's critique is directed at Descartes - or rather at what has become known as the Cartesian dualism. ${ }^{2}$ Ingold goes on to:

[...] suggest that a combination of "relational" thinking in anthropology, "ecological" thinking in psychology and "developmental" systems' thinking in biology would yield a synthesis infinitely more powerful than any of the "biosocial", "psychocultural" or "biopsychocultural" alternatives currently on offer, all of which invoke some version of the complementarity thesis (INGOLD, 2000, p. 1).

It is no coincidence that two of the major works by authors that Ingold mentions as his primary sources of inspiration contain the word ecology in their title: Steps to an ecology of mind from 1973 by the anthropologist Gregory Bateson and The ecological approach to visual perception from 1979 by the psychologist James J. Gibson.

Central to the ecological approach is a shift in focus from understanding the individual in an abstract or generalised environment to understanding the individual plus his or her concrete environment as a co-evolving entity, or as a dynamic system.

Bateson challenges the traditional sharp division between the internality of the organism and the externality of the environment with an example of a blind man with a stick. Bateson argues that the continuous information pathways between the blind man and his environment make it impossible or meaningless to identify the stick either as part of his internal self or as part of the external environment. The skin of the organism is, according to Bateson, no privileged boundary when it comes to understanding mental process.

Bateson in turn was heavily inspired by the cybernetic systems thinking of Norbert Wiener (HEIMS, 1993). In 1990 I attended a lecture by Heinz von Forster - a collaborator of Wiener, who explained cybernetics as the outcome of taking the static structure of mathematical equations and adding time. The addition of temporality made it possible to arrive at formal expressions of a dynamic, non-linear kind that later became the algorithms central to the operation of computers.

The cybernetic idea of circular information pathways (i.e. feed-back loops that cross the interior/exterior boundaries) paved the way for systems' thinking that eventually inspired modern ecology. 
The increased focus on temporality is also crucial to Ingold's project, which often involves a shift of focus from structure to process. Ingold challenges the ontological primacy of material "things" and instead focuses on the processes underlying their emergence. He writes "Let us agree that plants and animals, human and non-human, are all organisms. The question then arises: is an organism a thing or a being?" (INGOLD, 2000, p. 89).

Ingold rejects the idea that life could be a property of a discrete thing in the following way:

If life is a property of things, then it must be reducible to some internal principle, the possession of which distinguishes the class of objects we call organisms from classes of other kinds, and which - from its position within the organism - drives the latter's development and its interactions with the environment $[\ldots]$ if life is tantamount to being, then we have to regard the organism not so much as a living thing than as the material embodiment of a certain way of being alive. In other words, we should think of the organism not as containing life, or expressing it, but as emergent within the life process itself" (INGOLD, 2000, p. 89).

Here Ingold rejects the idea that the secret of life can be stored inside a thing. He rejects that DNA or any other structure within a thing can make this thing into a living organism, since the "thing-like" quality of an organism is secondary to its emergence from life as a process. Ingold tries to shift the ontological primacy of traditional science from structure to process.

Ingold's main strategy for overcoming the dualities of naturalistic science is a series of shifts of focus:

- Ingold relocates the main locus of human knowledge from the rational mind to the body embedded in its environment. Ingold traces the inspiration for this shift to the phenomenology of Heidegger and Merleau-Ponty.

- Just as Ingold rejects the idea that the essence of life can be stored as DNA-code inside a thing, he also rejects the idea that the essence of a culture can be stored as cultural codes and representations.

- He further relocates the main acquisition of knowledge from the intergenerational transmission of cultural codes, language, and representations to the organism's or person's growth and co-evolution in its total physical and mental environment.

- Ingold rejects the idea that the form of objects can be the sole result of a plan, a program or design imposed upon matter. 
- Instead Ingold leans on the concept of emergence that he uses to emphasise the importance of embedded processes, historicity and temporality.

Let us now consider how Ingold applies his theories to the analysis of a landscape. As an example of a landscape he uses the painting "The harvesters" from 1565 by Pieter Bruegel the Elder:

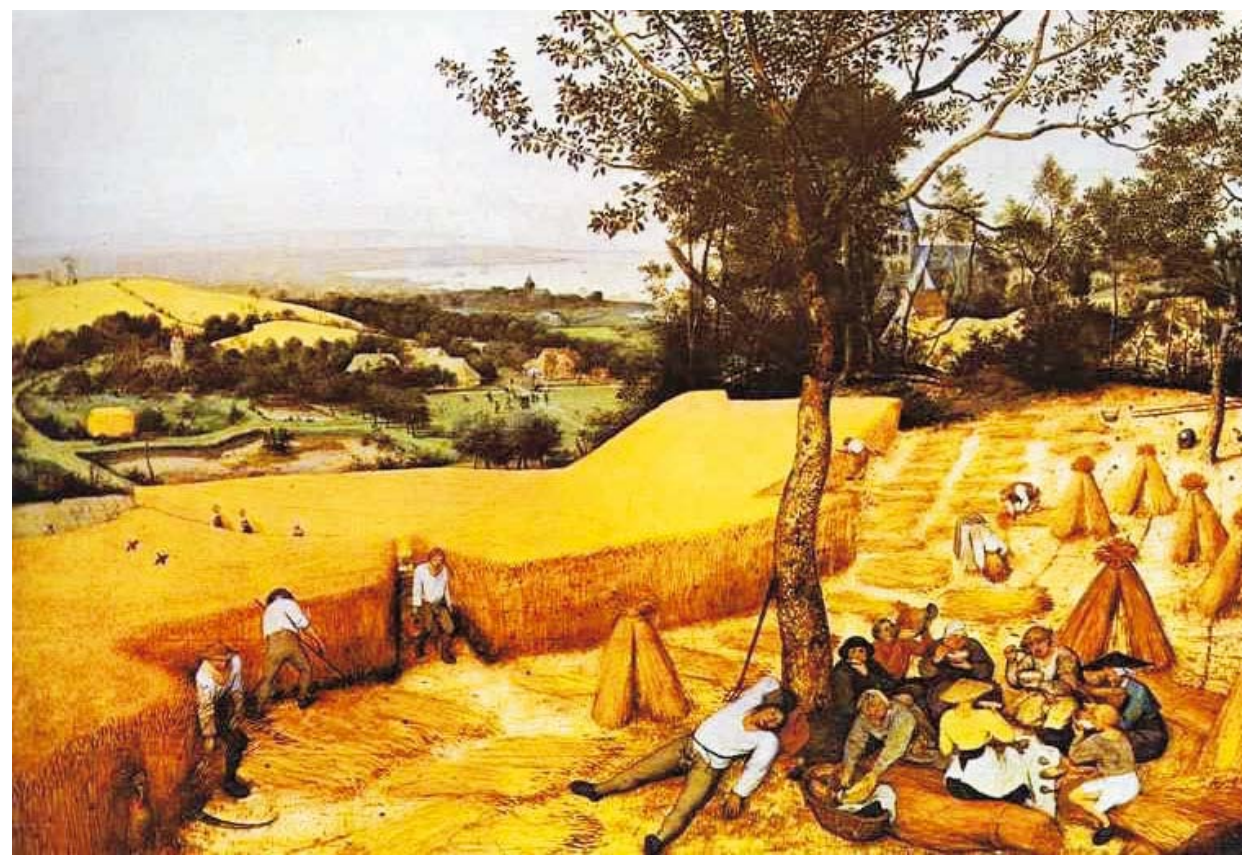

My purpose, in this chapter, is to bring the perspectives of archaeology and anthropology into unison through a focus on the temporality of the landscape. In particular, I believe that such a focus might enable us to move beyond the sterile opposition between the naturalistic view of the landscape as a neutral, external backdrop to human activities, and the culturalistic view that every landscape is a particular cognitive or symbolic ordering of space" (INGOLD, 2000, p. 189).

We see here that Ingold's ambition once again is to move beyond both realism and constructivism.

With this perspective of temporality in mind, Ingold finds that the important elements in the landscape are not things or persons, but tasks. And he coins the concept "taskscape". He then goes on to analyse the paths and tracks of Bruegel's landscape, and how they are related to the task of harvesting.

Thus the same movement is embodied, on the side of the people, in their "muscular consciousness", and on the side of the landscape, in its network of paths and tracks. In this 
network is sedimented the activity of an entire community, over many generations. It is the taskscape made visible (INGOLD, 2000, p. 204).

Then Ingold goes on to discuss the form of the central tree in front as well as the church visible just behind the other trees.

The final form of the church may indeed have been prefigured in the human imagination, but it no more issued from the image than did the form of the tree issue from its genes. In both cases, the form is the embodiment of a developmental or historical process, and is rooted in the context of human dwelling in the world (INGOLD, 2000, p. 206).

Similar ambitions to Ingold's are found in a growing interdisciplinary field that is often referred to as Studies of material culture.

The book by Christopher Tilley et al. (2006) Handbook of Material Culture sums up the current status of these material culture studies, and one contributor to the volume, the archaeologist Chris Godsen (2006, p. 425), writes:

As a parent it is possible to prepare a child to ride a bicycle by talking about balance, speed and when to turn the handlebars. But the real teacher is the bike itself, which will tune muscles, set up the faculty of balance and provide the social expectations of what other bike riders will do. Textiles, hand axes and fish stews are other vital teachers in human history.

This way of referring to a material object, the bike, as a teacher that will tune the muscles of the rider, resembles Ingold's descriptions of the people and tracks that mutually form each other in his taskscape.

The anthropologist Webb Keane in his article "Semiotics and the social analysis of material things", writes:

The goal is to open up social analysis to the historicity and social power of material things without reducing them either to being only vehicles of meaning, on the one hand, or ultimate determinants, on the other (KEANE, 2003, p. 411).

Here again we see a preoccupation with fighting on two fronts, both against matter as a passive carrier of meaning and against matter as a determining factor in the realm of physics. But determinism is not confined to physics. Keane sees Saussure's separation of "langue" and "parole", as a precondition for considering language (or langue) as a semiotic system which determines the meaning of its elements in ways similar to the necessities of mathematics.

[A]nalyzing language as a system of differences requires a degree of abstraction such that only certain kinds of difference 
are significant. Actual material differences between instances of speaking simply do not count in linguistic terms. Rather, what he [Saussure] called 'semiology' concerns only virtual types, not concrete tokens (KEANE, 2003, p. 12).

The formalisation and dematerialisation of language brings it closer to mathematics and logic.

Saussurean analysis is confined to relations among signifiers and signifieds. Since signifieds are conceptual in nature, they too are part of the linguistic system (that is, they are meanings, not actual objects of reference). [...] the doctrine of arbitrariness, strictly speaking, applies only to relations between signs and the world of referents. Relations among the elements within the system are mutually determining and therefore not arbitrary in the way we usually understand the word (KEANE, 2003, p. 412).

We can now identify the following steps in the history of materiality.

Through the scientific revolution, the movements of material bodies became associated with determinism. But this determinism was not a direct consequence of materiality itself. Rather, it was the coupling of the material with something quite immaterial, namely the persuasive necessity of mathematics that created the halo of determinism associated with materiality.

The romantic turn can be seen, inter alia, as an attempt to escape from the deterministic hegemony of natural science. With a focus away from the material, towards ideas, language, poetry, creativity and the unique, the romantics sought everything that could escape the determining laws of nature. But the focus on a unique inner reality also strengthened the idea of constructivism.

The linguistic turn and structuralism after Saussure, can be seen as another invasion of determinism. This time it was not mathematics colonising the material world, but linguistics and semiology colonising ideas and meaning.

A third wave of deterministic formalisations stems from DNA and molecular biology colonising our understanding of life. To some extent, this can be seen as strengthening the deterministic power of both physical matter and linguistic code.

One could see the efforts of Ingold and his fellows as a new romantic reaction, this time trying to escape determinism, not by fleeing from the material and the external into the unique inner world of the individual self, but by embracing materiality and externality as parts of an equally unique human dwelling in the environment, shifting the focus of attention from the individual to larger ecological processes.

I am not convinced that Ingold has succeded in overcoming any of the great dualities he challenges, but I sympathise with his efforts. 


\section{Notes}

${ }^{1}$ Paper presented at the joint meeting of Cheiron and the European Society for the History of the Human Sciences (ESHHS) in Dublin, June 25-29 2007. To be published in "Fractal Revista de Psicologia".

${ }^{2}$ I.e. a common understanding of Descartes, which is not necessarily congruent with the views Descartes actually argued (cf. KIRKEBØEN, 2001).

\section{REFERENCES}

BATESON, G. Steps to an ecology of mind. London: Fontana, 1973.

BRUEGEL, P. (the Elder). The harvesters. 1565. Oil on wood $461 / 2 \times 631 / 4 \mathrm{in}$. $(118,1 \times 160,7 \mathrm{~cm})$. Metropolitan Museum of Art, New York. Pieter_Bruegel the Elder-_The_Corn_Harvest_(August).JPG' $(753 \times 517$ pixels, file size: 86 KB, MIME type: image/jpeg). Disponível em <http://www.metmuseum.org/ toah/ho/08/euwl/hod_19.164.htm\#>. Acesso em: 23 out. 2007.

GIBSON, J. J. The ecological approach to visual perception. Boston: H. Mifflin, 1979.

GODSEN, C. Material culture and long-term change. In: TILLEY, C. et al. (Ed.). Handbook of Material Culture. London: Sage, 2006. p. 425-442.

HEIMS, S. J. Constructing a Social Science for Postwar America : the Cybernetics Group, 1946-1953. Cambridge, Mass.: MIT Press, 1993.

INGOLD, T. The perception of the environment: essays in livelihood, dwelling and skill. London: Routledge, 2000.

KEANE, W. Semiotics and the social analysis of material things. Language \& Communication, [S.1.], v. 23, p. 409-425, 2003.

KIRKEBØEN, G. Descartes' Embodied Psychology: Descartes' or Damasio's error?. Journal of the History of the Neurosciences, [S.1.], v. 10, n. 2, p. 173-191, 2001.

SINDING-LARSEN, H. Computers, musical notation and the externalisation of knowledge: towards a comparative study in the history of information technology. In: NEGROTTI, M. (Ed.). Understanding the Artificial: on the future shape of Artificial Intelligence. London: Springer-Verlag, 1991. p. 101-125.

TILLEY, C. et al. (Ed.) Handbook of Material Culture. London: Sage, 2006. 
Externality and materiality as themes in the history of the human sciences

\section{ACKNOWLEDGEMENTS}

The author thanks Geir Kirkebøen, Tord Larsen and Finn Sivert Nielsen for helpful comments to the draft.

Recebido em: outubro de 2007

Aceito em: fevereiro de 2008 